\title{
MANAGEMENT OF YOUNG WOMEN WITH EARLY BREAST CANCER - FOCUS ON FERTILITY PRESERVATION
}

\author{
PETRA VUKOVIĆ ${ }^{1}$, JELENA RAGUŽ ${ }^{1}$ and LIDIJA BEKETIĆ-OREŠKOVIĆ1,2 \\ ${ }^{1}$ Division of Radiotherapy and Medical Oncology, University Hospital for Tumors, \\ Sestre milosrdnice University Hospital Center, Zagreb, Croatia \\ ${ }^{2}$ Department of Clinical Oncology, School of Medicine, University of Zagreb, Zagreb, Croatia
}

\begin{abstract}
Summary
Management of young women with breast cancer is complex and has several particularities, one of which is fertility preservation, a very important quality of life issue for young breast cancer survivors. Chemotherapy can be gonadotoxic and significantly reduce woman`s reproductive potential and cause premature ovarian insufficiency while endocrine therapy requires a delay of pregnancy and indirectly affects fertility. Therefore every woman of reproductive age diagnosed with breast cancer should be informed about potential gonadotoxic effect of cancer treatment, the risk of premature ovarian insufficiency and associated symptoms, available fertility preservation methods, delay of cancer treatment and chances of subsequent pregnancy. If interested in fertility preservation breast cancer patients should be referred as early as possible to a reproductive specialist to further discuss the risk of infertility and available fertility preservation options. Currently established methods for fertility preservation are embryo and oocyte cryopreservation, while ovarian tissue cryopreservation, cryopreservation of immature oocytes and ovarian suppression with gonadotropin-releasing hormone agonists are still considered experimental.

The aim of this review is to highlight the importance of fertility preservation as an important quality of life issue for young breast cancer survivors.
\end{abstract}

KEY WORDS: breast cancer, fertility preservation, pregnancy, quality of life.

\section{LIJEČENJE MLADIH ŽENA S RANIM STADIJEM RAKA DOJKE - VAŽNOST OČUVANJA PLODNOSTI}

\section{Sažetak}

Liječenje mladih žena s rakom dojke je složeno i ima nekoliko posebnosti, jedna od kojih je očuvanje plodnosti, vrlo bitan čimbenik kvalitete života mladih žena koje su preboljele rak dojke. Kemoterapija može štetno utjecati na jajnike i značajno smanjiti reprodukcijski potencijal žene i uzrokovati prijevremenu ovarijsku insuficijenciju, dok endokrina terapija zahtijeva odgodu trudnoće i tako posredno utječe na plodnost. Stoga bi svaka žena, kojoj je rak dojke dijagnosticiran u reprodukcijskoj dobi, trebala biti informirana o mogućem gonadotoksičnom učinku antineoplastičke terapije, riziku prijevremene ovarijske insuficijencije i povezanim simptomima, dostupnim metodama očuvanja plodnosti, odgodi sustavne antineoplastičke terapije, kao i o mogućnostima ostvarenja trudnoće nakon provedenog liječenja. Ukoliko je bolesnica s rakom dojke zainteresirana za očuvanje plodnosti, treba je što ranije uputiti subspecijalistu humane reprodukcije, koji će joj dodatno objasniti rizike za neplodnost i dostupne metode očuvanja plodnosti. Krioprezervacija embrija i oocita su trenutno jedine etablirane metode očuvanja plodnosti, dok se krioprezervacija tkiva jajnika, krioprezervacija nezrelih oocita i ovarijska supresija još uvijek smatraju eksperimentalnima.

Cilj ovoga preglednog rada je istaknuti važnost očuvanja plodnosti kao bitnog čimbenika kvalitete života mladih žena koje su preboljele rak dojke.

KLJUČNE RIJEČI: rak dojke, očuvanje plodnosti, trudnoća, kvaliteta života. 


\section{INTRODUCTION}

Advances in the breast cancer (BC) treatment have increased survival rates of $B C$ patients. One of the most important survivorship issues for young BC patient is fertility preservation because cancer treatment can be gonadotoxic and reduce the reproductive potential of young women. Breast cancer therapy can affect fertility both directly with administration of gonadotoxic chemotherapy to ovaries and indirectly in case of HRpositive $\mathrm{BC}$ with the administration of endocrine therapy. Because of teratogenic potential of endocrine therapy, pregnancy is contraindicated during 5 year or longer period of this therapy (1). Data suggest that young women have unique biology and more aggressive phenotypes of BC. However, according to current recommendations the same factors should be taken into account for older and young BC patients for decision of which therapy to prescribe $(2,3)$. Younger women are often candidates for gonadotoxic chemotherapy and in case of HR-positive BC subsequently for endocrine therapy. These treatments can significantly impair their fertility. The postponement of fertility in contemporary societies results in increased number of young patients diagnosed with $\mathrm{BC}$ who have not yet completed their family and wish to preserve fertility and achieve subsequent pregnancy (4).

\section{Pregnancy after breast cancer}

Current retrospective evidence suggests that pregnancy after $\mathrm{BC}$ is not associated with an increased risk of recurrence and should not be discouraged, even in case of HR-positive BC. Although optimal timing for conception after $\mathrm{BC}$ is unknown, it is suggested that early pregnancy (during the first 2 years from $\mathrm{BC}$ diagnosis) should be avoided. It is recommended to wait 3-6 months after treatment interruption and pregnancy attempt to allow wash-out of endocrine therapy. Also, there is no evidence supporting a therapeutic role of induced abortion $(5,6,7,8,9)$.

Currently ongoing prospective POSITIVE (Pregnancy Outcome and Safety of Interrupting Therapy for Women with Endocrine Responsive BC, ClinicalTrials.gov Identifier: NCT02308085) study will attempt to answer a lot of open questions in the oncofertility field, particularly safety of endocrine therapy interruption in HR-positive
BC. Also, BC patients have increased risks of delivery complications (cesarean section, preterm delivery and low birth weight) and should be closely monitored during pregnancy (8). Patients should be strongly advised to avoid pregnancy during active cancer treatment due to teratogenic potential of both chemotherapy and endocrine therapy. Barrier methods such as condoms and cervical diaphragm and copper IUDs or male contraception are recommended, while hormone contraception is contraindicated (5).

\section{Fertility consultation}

Young premenopausal BC patients should be informed about the biology of $\mathrm{BC}$, proposed treatment options and expected benefits, potential gonadotoxic effect of planned treatment for $\mathrm{BC}$, risk of premature ovarian insufficiency (POI) and associated symptoms (vasomotor symptoms, weight gain, sexual dysfunction, sleep disorders, osteoporosis, atherosclerosis) and infertility, available fertility preservation options, safety and potential timing of subsequent pregnancy, delay of cancer treatment initiation and, if interested in fertility preservation, $\mathrm{BC}$ patients should be referred to a reproductive specialist early as possible to further discuss the risk of infertility and available options for fertility preservation. A multidisciplinary approach to fertility preservation and early referral are the key components for the successful fertility preservation which allows young BC survivors to have their own biological family in the future $(8,10)$.

Gonadotoxicity is dependent on the age of the patient, remaining ovarian reserve, type and the dose of planned chemotherapy. Older women have a greater risk of POI because they have naturally reduced ovarian reserve. Patients with previous exposure to gonadotoxic therapy, autoimmune disease, endometriosis have increased risk of POI (11). Among different chemotherapy agents, cyclophosphamide is considered to be the most gonadotoxic. Cyclophosphamide is a cell-cycle nonspecific alkylating agent which causes damage to resting and growing follicles in a dose-dependent manner $(12,13)$. Ovarian reserve can be assessed by hormone assays (Anti-Mullerian hormone, follicle-stimulating hormone (FSH), estradiol, inhibin-B) and antral follicle count with transvaginal ultrasound in the early follicular phase (14). 


\section{Fertility preservaton options}

Gold standard methods for fertility preservation are embryo and mature oocyte cryopreservation both of which require ovarian stimulation (OS) and delay initiation of chemotherapy for at least 2 weeks with the use of random start OS protocols $(15,16,17)$. The success of both of these methods is highly dependent on the age of the patients, reproductive history and number of stored oocytes or embryos. In order to achieve a sufficient number of oocytes for cryopreservation process OS needs to be performed. Because of concerns that OS would increase significantly estradiol levels and increase the risk of $B C$ recurrence in HR-positive BC alternative and safer protocols for OS using letrozole with gonadotropins were developed which are considered to be safe and effective $(18,19,20,21)$. Reported live birth per embryo transfer is $45 \%$ which is comparable to patients using IVF because of infertility (20).

For those women unable to undergo embryo cryopreservation because of law restriction, religious and ethical reasons, lack of partner or unwillingness to use sperm donor alternative to embryo cryopreservation is oocyte cryopreservation. With the use of vitrification oocyte cryopreservation has improved live birth rates. Reported live birth rate per patient was higher in patients younger than 35 years (live birth rate of $50 \%$ compared to $22.9 \%$ for women older than 36 years), needing at least 8-10 metaphase II oocytes for successful outcome, with individualization of numbers of oocytes for women older than 36 years (22).

Other fertility preservation methods include ovarian tissue cryopreservation, cryopreservation of immature oocytes, ovarian suppression with gonadotropin-releasing hormone agonists (GnRHa) which are still considered experimental in fertility preservation. A great advantage of these methods is that they do not require OS and therefore can be used in patients who cannot delay start of cancer treatment.

Administration of GnRHa is the only noninvasive fertility preservation procedure which does not require the use of assisted reproductive technologies, therefore, it is significantly less expensive than other methods. There has been a lot of controversy regarding the use of GnRHa as a fertility preservation method. Although exact mechanism of action of GnRHa that could protect is currently uncertain it has been suggested that GnRHa could protect the ovaries from the gonadotoxic effect of chemotherapy with induction of gonadal quiescence and prevention of ovarian burnout fenomen, reduction of ovarian blood flow which could decrease the delivery of chemotherapy to ovaries as well with the upregulation of antiapoptotic pathways (23). On the contrary others stated that primordial follicles do not express gonadotropin receptors so GnRHa could not have direct effect on them and protect ovaries from the gonadotoxic effect of chemotherapy and pointed out that the majority of studies which evaluated the efficacy of GnRHa did not include adequate endpoints to measure fertility (24). Recent metaanalysis showed that when given concurrently with chemotherapy GnRHa resulted in reduced risk of POI (OR 0.38 ; 95\% CI 0.26-0.57) which is also very important issue for the quality of life of young patients taking into consideration all the symptoms associated with early menopause. Metaanalysis also showed higher chance for subsequent pregnancy; $10.5 \%$ in patients who received GnRHa, compared to $5.5 \%$ of pregnancies in control group, incidence rate ratio $1.83 ; 95 \% \mathrm{CI}$, 1.06 to 3.15 (25). Current ASCO guidelines recommend using GnRHa to reduce the likelihood of chemotherapy-induced ovarian insufficiency and when other fertility preservation methods such as oocyte, embryo or ovarian tissue cryopreservation are not available (15).

In vitro maturation (IVM) is a technique which involves harvesting of immature oocytes from unstimulated ovaries or ovarian tissue are maturation in vitro. A high antral count is very important for the success of this method. Success rates of IVM are much lower compared to standard IVF, it is more expensive and technically more demanding $(26,27)$.

Ovarian tissue cryopreservation is attractive fertility preservation method in which ovarian tissue is harvested laparoscopically, cryopreserved and transplanted back to the patient either into pelvis cavity (orthotopic site) or extrapelvic site (heterotopic site) when a patient wants to use their ovarian tissue. Ovarian tissue cryopreservation has the advantage of restoring endocrine function, in more than $95 \%$ of patients when performed orthotopically. More than 130 babies have been born using this method with a pregnancy rate of $29 \%$. Furthermore, orthotopic transplantation allows 
spontaneous pregnancy (28). Posttransplantation ischemia is a significant problem for this method and the age of the patient should be taken into account when using this method. Therefore ovarian tissue cryopreservation is recommended to patient younger than 35 years who have good ovarian reserve with a real chance of 5 -year survival who have $50 \%$ risk of POI (28). Ovarian tissue needs to be examined by histology and molecular biological techniques before returned to patient to exclude malignant reseeding of cancer cells. Further developments in this field to avoid reimplantation of malignant cells include isolation of primordial follicles and formation of the artificial ovary $(28,29)$.

\section{CONCLUSION}

Infertility is a devastating adverse consequence which can occur after successful oncological treatment and cause a great deal of psychological distress and depression for young women who have not completed their family prior to BC diagnosis. Therefore fertility preservation has emerged as a very important quality of life issue for these patients. Every woman of reproductive age diagnosed with $\mathrm{BC}$ should be informed about potential adverse effect of cancer treatment and its effect on fertility and, if interested in fertility preservation, should be early referred to a reproductive specialist to further discuss the risk of infertility and available fertility preservation options.

\section{REFERENCES}

1. Trivers KF, Fink AK, Partridge AH, Oktay K, Ginsburg ES, Li C et al. Estimates of young breast cancer survivors at risk for infertility in the U.S. Oncologist. 2014;19(8):814-22. Paluch-Shimon S, Pagani O, Partridge AH, Abulkhair O, Cardoso M-J, Dent RA, et al. ESO-ESMO 3rd international consensus guidelines for breast cancer in young women (BCY3). Breast 2017; 35:203e17.

2. Azim HA Jr, Partridge AH. Biology of breast cancer in young women. Breast Cancer Res. 2014;16:427.

3. Kasum M, Beketić-Orešković L, Peddi PF, Orešković S, Johnson RH. Fertility after breast cancer treatment. Eur J Obstet Gynecol Reprod Biol. 2014;173:13-8.

4. Paluch-Shimon S, Pagani O, Partridge AH, Abulkhair O, Cardoso M-J, Dent RA, et al. ESO-ESMO 3rd international consensus guidelines for breast cancer in young women (BCY3). Breast 2017;35:203e17.
5. Azim HA Jr, Santoro L, Pavlidis N, Gelber S, Kroman $\mathrm{N}$, Azim H, et al. Safety of pregnancy following breast cancer diagnosis: a meta-analysis of 14 studies. Eur J Cancer. 2011;47(1):74-83.

6. Kasum M, Beketić-Orešković L, Orešković S. Subsequent pregnancy and prognosis in breast cancer survivors. Acta Clin Croat. 2014;53(3):334-41.

7. Lambertini M, Del Mastro L, Pescio MC, Andersen CY, Azim HA Jr, Peccatori FA, et al. Cancer and fertility preservation: international recommendations from an expert meeting. BMC Med. 2016;14:1.

8. Lambertini M, Kroman N, Ameye L, Cordoba O, Pinto A, Benedetti G. Long-term Safety of Pregnancy Following Breast Cancer According to Estrogen Receptor Status. J Natl Cancer Inst. 2018;110:426-429.

9. Lee S, Ozkavukcu S, Heytens E, Moy F, Oktay K. Value of Early Referral to Fertility Preservation in Young Women With Breast Cancer. J Clin Oncol. 2010; 28(31): 4683-4686.

10. Martinez F; International Society for Fertility Preservation-ESHRE-ASRM Expert Working Group. Update on fertility preservation from the Barcelona International Society for Fertility Preservation-ESHRE-ASRM 2015 expert meeting: indications, results and future perspectives. Fertil Steril. 2017;108(3):407-415.e11.

11. Taylan E, Oktay K. Current state and controversies in fertility preservation in women with breast cancer. World J Clin Oncol 2017;8(3):241-248.

12. Bines J, Oleske DM, Cobleigh MA. Ovarian function in premenopausal women treated with adjuvant chemotherapy for breast cancer. J Clin Oncol 1996;14: 1718-1729.

13. Bedoschi G, Navarro PA, Oktay K Chemotherapy-induced damage to ovary: mechanisms and clinical impact. Future Oncol. 2016;12(20):2333-44.

14. Oktay K, Harvey BE, Partridge AH, Quinn GP, Reinecke J, Taylor HS.Fertility Preservation in Patients With Cancer: ASCO Clinical Practice Guideline Update. J Clin Oncol. 2018;36:1994-2001.

15. von Wolff $M$, Thaler CJ, Frambach $T$ et al. Ovarian stimulation to cryopreserve fertilized oocytes in cancer patients can be started in the luteal phase. Fertil Steril 2009; 92:1360-5.

16. Cakmak H, Katz A, Cedars MI, Rosen MP. Effective method for emergency fertility preservation: Randomstart controlled ovarian stimulation. Fertil Steril 2013; 100:1673-80.

17. Kasum M, von Wolff M, Franulić D, Čehić E, KlepacPulanić $T$, Orešković $S$, et al. Fertility preservation options in breast cancer patients. Gynecol Endocrinol. 2015;31:846-51.

18. Rodriguez-Wallberg KA, Eloranta S, Krawiec K, Lissmats A, Bergh J, Liljegren A. Safety of fertility preservation in breast cancer patients in a register-based matched cohort study. Breast Cancer Res Treat. 2018; 167:761-769. 
19. Oktay K, Turan V, Bedoschi G, Pacheco FS, Moy F. Fertility Preservation Success Subsequent to Concurrent Aromatase Inhibitor Treatment and Ovarian Stimulation in Women With Breast Cancer. J Clin Oncol. 2015; 33:2424-9.

20. Kim J, Turan V, Oktay K (2016) Long-term safety of letrozole and gonadotropin stimulation for fertility preservation in women with breast cancer. J Clin Endocrinol Metab 101:1364-1371.

21. Cobo A, García-Velasco JA, Coello A, Domingo J, Pellicer A, Remohí J. Oocyte vitrification as an efficient option for elective fertility preservation. Fertil Steril. 2016;105:755-764.e8.

22. Blumenfeld Z. How to preserve fertility in young women exposed to chemotherapy? The role of $\mathrm{GnRH}$ agonist cotreatment in addition to cryopreservation of embryo, oocytes, or ovaries. Oncologist. 2007;12: 1044-54.

23. Taylan E, Oktay K. Current state and controversies in fertility preservation in women with breast cancer. World J Clin Oncol 2017;8:241-248.

24. Lambertini M, Moore HCF, Leonard RCF, Loibl S, Munster P, Bruzzone M, et al. Gonadotropin-Releasing Hormone Agonists During Chemotherapy for Preservation of Ovarian Function and Fertility in Premenopausal Patients With Early Breast Cancer: A Sys- tematic Review and Meta-Analysis of Individual Patient-Level Data. J Clin Oncol. 2018;36:1981-1990.

25. Practice Committees of the American Society for Reproductive Medicine and the Society for Assisted Reproductive Technology. In vitro maturation: a committee opinion. Fertil Steril. 2013;99:663-6.

26. Guenther V, Alkatout I, Junkers W, Bauerschlag D, Maass N, von Otte S.Fertility Preservation in Female Patients with Breast Cancer - a Current Overview. Geburtshilfe Frauenheilkd. 2017;77:1088-1094.

27. Donnez J, Dolmans MM. Fertility Preservation in Women. N Engl J Med 2017;377:1657-1665.

28. Anderson RA, Wallace WHB, Telfer EE. Ovarian tissue cryopreservation for fertility preservation: clinical and research perspectives. Hum Reprod Open 2017;1.

Corresponding author: Lidija Beketić-Orešković, Department of Clinical Oncology, School of Medicine, University of Zagreb, Zagreb, Croatia and Division of Radiotherapy and Medical Oncology, University Hospital for Tumors, Sestre milosrdnice University Hospital Center, Ilica 197, 10000 Zagreb, Croatia. e-mail: lidijabeketicoreskovic@gmail.com 